\title{
Alternative Development Designs of a Culinary Center in Surabaya that Attract more Customers
}

\author{
S Azizah ${ }^{1}$ \\ ${ }^{1}$ Department of Civil Architecture, Institut Teknologi Adhi Tama Surabaya, Surabaya 60117, \\ Indonesia \\ azizah@itats.ac.id
}

\begin{abstract}
The action taken by Surabaya city government in dealing with street vendors was by relocating street vendors to areas named Sentra Kuliner (culinary center). Those culinary centers were built to particularly provide space for street vendors who sell food. However, in reality, some culinary centers were not visited by many customers. One of which was Sentra Kuliner Gunung Anyar. Concerned by that issue, the researchers aimed to develop those uncrowded culinary centers by creating some alternative designs that would improve the existing design so that those culinary centers could attract more customers and please the relocated street vendors. This study used Research and Development (R\&D) method. The result showed respondents' preference to alternative design that look more conspicuous than other buildings around and have more attractive appearance than that of the original design. Adding supportive amenities to the alternative design will also increase public attention as well.
\end{abstract}

\section{Introduction}

Dealing with street vendors in big cities like Surabaya is almost like facing an unsolvable problem. Nevertheless, Surabaya city government has taken an action to overcome that problem. The city government relocated undisciplined street vendors selling food at unauthorized places such as sidewalks and city parks to a facility called Sentra Kuliner (culinary centers).

Related to this program, currently Surabaya has tens of culinary centers operating. The program has helped many street vendors to improve their life quality and has contributed to make the city cleaner, beautiful, and orderly. However, a new problem arose. It was to figure out how to ensure that many people would be attracted to visit the culinary centers so that the culinary centers would survive long. This because in reality, not all of those operating culinary centers attracted many visitors. Some culinary centers did not have many visitors and would very likely be out of business in the near future. One of those unfortunate culinary centers is Sentra Kuliner Gunung Anyar which is located in east Surabaya.

When Sentra Kuliner Gunung Anyar first opened, the place accommodated many food vendors and the visitors were quite a crowd. However, the number of visitors had significantly decreased, which in turn caused the leaving of some vendors due to lack of income. Until this research was conducted, there had been only several relocated street vendors still selling at the culinary centers.

Concerned by that reason, the researcher aimed to improve the design of Sentra Kuliner Gunung Anyar by creating some alternative designs based on the existing design. The objective was to make the culinary center become more attractive for both visitors and the street vendors within. 


\section{Introduction}

According to Bromley, R the concern that street vendors will bring out municipal problem's triggers two kinds of response [1]. Some people believe that street vendors only cause problems and therefore should be banned. Some others are supportive of the streets vendors selling in the city.

Meanwhile, according to Madanipour, the rejection of street vendors is a manifestation and a social exclusion in some cities [2]. Excluding poor members of the society may cause public spaces disorderly. Concerning the same matter, Andri Y argued that street vendors will never cease to exist despite the efforts to erase them from urban environments since they are irreplaceable from city economy [3].

Furthermore, according to Ala'Eddin there are many important factors in transforming traditional shopping markets to modern shopping malls [4]. These factors include economic problems, economic wealth, shifted lifestyle, cultural diversity, ethnicity, and the space's atmosphere. In addition, Sharma and Dhanwantri stated that concerning the interior of food court-type public spaces, modern concepts can be implemented by adding partition design, geometric patterned ornaments, and using stainless steel-based materials [5].

The results of Azizah, research on the designs favored by street vendors and users are locations that are close to other public facilities, modern building forms, interiors have a relaxed yet dynamic atmosphere, shaded and green exterior and supporting facilities such as entertainment stages [6]. Whereas Candra has a concept in the culinary center arrangement that culinary center stands display visual sense through the stand form, and the sense of motion through a semicircular stand arrangement [7]. cooking demonstration area that displays visual sense and sense of smell. According to Azizah, in order to create environmental aesthetics in the city center strived with a physical arrangement model in the form of street vendors zoning according to the type of merchandise, in addition to regulating the placement, size and shape of selling equipment and free space for pedestrians [8]. In connection with the interior of public spaces such as food court delivered by Sharma P and Dhanwantri that modern concepts can be applied with the design of partitions and ornaments with geometric patterns and also the use of stainless-steel materials [5]. According to Sitanaya, Octofiany and Handinoto, facilities in Tourism Culinary is a public space that can highlight the function of culinary tourism [9]. These facilities include food court, coffee shop, souvenir shop, recreation area and also supporting facilities such as play area, multipurpose room, book cafe, meeting room, office management and service. The emphasis in design is in the form of concepts, space characters, and landscape arrangement

\section{Methodology}

The method used in this research was Research and Development (R\&D). This research continued the previous research on the same field: Design Aspects of Culinary Centers in Surabaya, Indonesia by Azizah [6]. Azizah found that culinary center design aspects wanted by sellers are: location that is near other public facilities, modern setting, lively and more dynamic interior design, more outdoor plants and spacious parking area [6]. Culinary centers are supported by other amenities in it. Two alternative culinary center designs were then developed from those aspects. The researchers then used both alternative designs to obtain data about development design favored by respondents (street vendors and visitors).

\section{Result and Discussion}

Based on the initial research by Azizah, two alternative development designs of Sentra Kuliner Gunung Anyar were made [6]. 


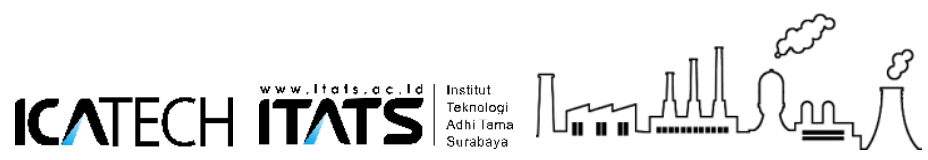

The $1^{\text {st }}$ International Conference on Advanced Engineering and Technology - 2018

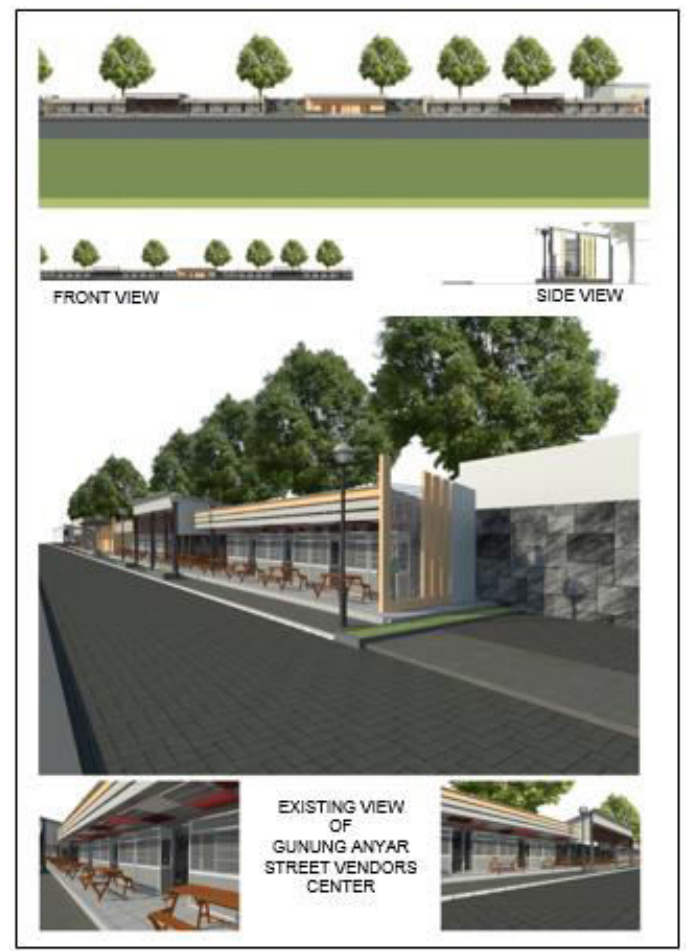

Figure 1. Front view and existing design perspective of Sentra Kuliner Gunung Anyar.

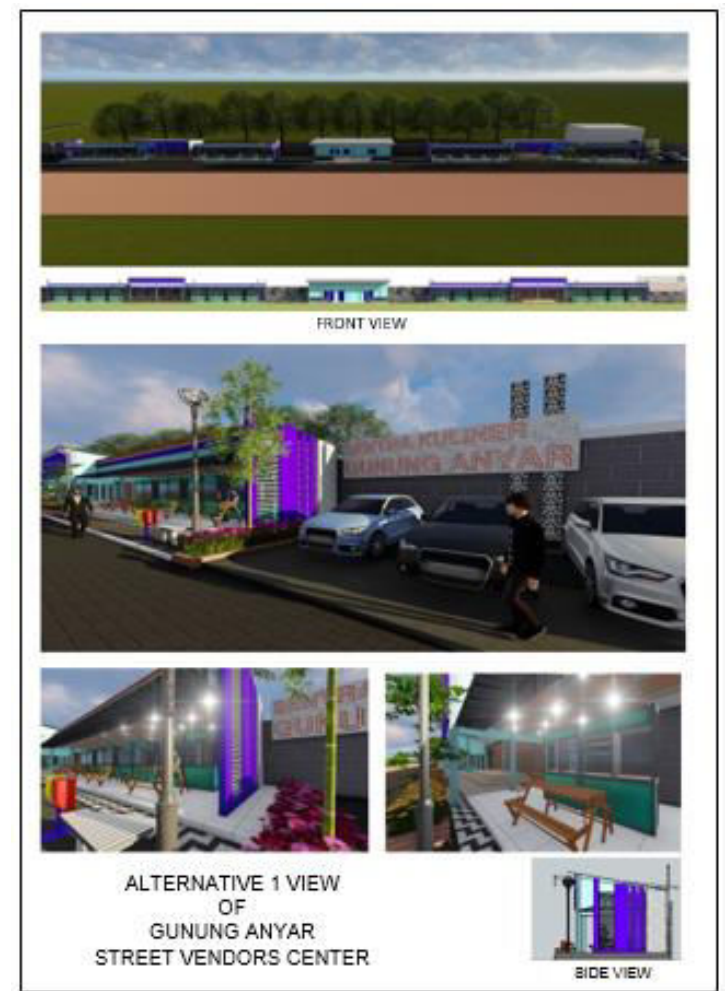

Figure 2. Alternative development design 1 of Sentra Kuliner Gunung Anyar. The roof is constructed with overhangs and the building is painted with attractive colors. The facility has a playground, a music stage, and a name sign that can be clearly seen from a distance. 


\section{ICATECH ITATS}

The $1^{\text {st }}$ International Conference on Advanced Engineering and Technology - 2018

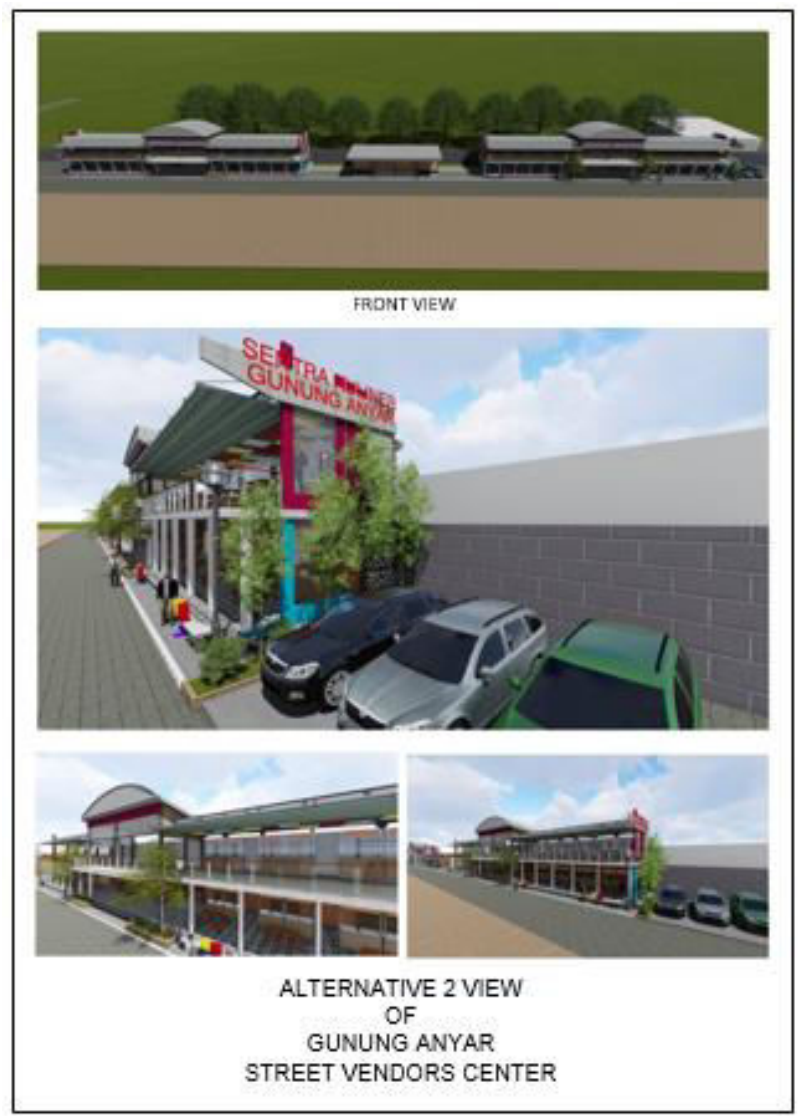

Figure 3. Alternative development design number 2 of Sentra Kuliner Gunung Anyar. 2 storybuilding design was chosen so that the building can be seen from a distance. The building has playground, music stage, and a name sign at the front of the building that can be clearly seen from a distance.

Questionnaires given to the respondents (street vendors and visitors) showed that most of the respondents chose alternative design 2 . The reason was that 2-story building would be easily recognized from a distance, unlike the current 1-story building (existing design) that did not look very different from other buildings in the environment. The existing culinary center building was not easily identifiable or recognized by both passersby and visitors.

Besides, alternative design 2 was considered more attractive and grander so that it potentially would attract more attention. In addition, the use of metallic paint colors and geometric ornaments gave stronger modern impression to the building.

Furthermore, the respondents believed that adding playground and music stage would attract more customers because that way not only adults, but also kids and youngsters would be interested in coming to the culinary center as well.

The addition of easily seen name sign was believed would catch passersby attention. Moreover, the building that was designed to be 1-story taller than any other building around would get better air circulation and induce better atmosphere.

\section{Conclusion}

It can be concluded from the research that: Music stage and playground were supporting facilities desired most by building users. More activity during the day will attract more daytime visitors. Building should be painted with brighter and conspicuous colors to attract more attention. The presence of many plants was favourable since it certainly would bring more fresh air and shade to the 


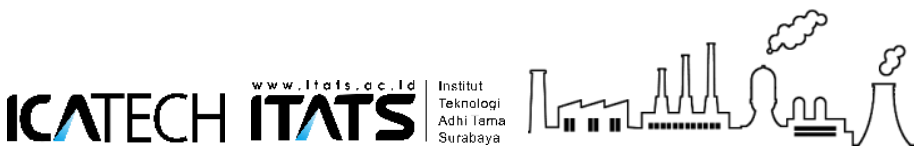

The $1^{\text {st }}$ International Conference on Advanced Engineering and Technology - 2018

building. Lighting should be bright so that the building will be clearly visible from nearby road. Building name sign will help attract passers-by attention.

\section{References}

[1] R. Bromley, "Street vending and public policy: a global review," Int. J. Sociol. Soc. Policy, vol. 20 , no. $1 / 2$, pp. 1-29, 2000.

[2] A. Madanipour, "Marginal public spaces in European cities," J. Urban Des., vol. 9, no. 3, pp. 267-286, 2004.

[3] Y. Andri Y, "Street Vendors as 'out of Place' Urban Elements," J. Urban Des., vol. 13, no. 3, pp. 387-402, 2008.

[4] M. K. A. Ala'Eddin, "Attractiveness Factors Influencing Shoppers' Satisfaction, Loyalty, and Word of Mouth: An Empirical Investigation of Saudi Arabia Shopping Malls," Int. J. Bus. Adm., vol. 3, no. 6, pp. 101-112, 2012.

[5] P. Sharma and K. Dhanwantri, "Application of Materials in Interior Design," Int. Educ. Appl. Sci. Res. J., vol. 2, no. 7, pp. 3-4, 2017.

[6] S. Azizah, "Location and Design Aspect in Culinary Center Building Design Development For Business Sustainability of Street Vendors in Surabaya, Indonesia," Int. J. Adv. Res., vol. 5, no. 10, pp. 1326-1331, 2017.

[7] R. Candra, "Pusat kuliner Khas Solo di Solo," 2013. .

[8] S. Azizah, "Street Vendors Arrangement Model Downtown," J. Archit. Environ., vol. 6, no. 2, pp. 105-113, 2007.

[9] O. Sitanaya and Handinoto, "Fasilitas Wisata Kuliner di Surabaya," J. eDimension Archit., vol. 1, no. 1, pp. 1-6, 2012. 